\title{
H2BC10 wt Allele
}

National Cancer Institute

\section{Source}

National Cancer Institute. H2BC10 wt Allele. NCI Thesaurus. Code C162933.

Human $\mathrm{H} 2 \mathrm{BC} 10$ wild-type allele is located in the vicinity of $6 \mathrm{p} 22.2$ and is approximately 1 $\mathrm{kb}$ in length. This allele, which encodes histone $\mathrm{H} 2 \mathrm{~B}$ type 1-C/E/F/G/I protein, plays a role in chromosomal compaction. 